\title{
EKSISTENSI PEMENTASAN WAYANG KULIT PARWA SUKAWATI \\ PADA ERA GLOBALISASI
}

I Nyoman Sudanta

\author{
Fakultas Ilmu Agama, Seni dan Budaya \\ Universitas Hindu Indonesia
}

\begin{abstract}
ABSTRAK
Artikel ini mengkaji tentang eksistensi Wayang Kulit Parwa Sukawati di Era Globalisasi. Bertahannya wayang kulit Parwa Sukawati pada era Globalisasi meliputi faktor sebagai berikut yakni: (1) Tumbuh Daya Kreativitas dan Inovasi Para Dalang Wayang Kulit Parwa Sukawati Dalam Menghadapi Era Globalisasi, yaitu berkembangnya kreativitas para dalang, namun kekhasan pementasan Wayang Kulit Sukawati yang lebih menonjolkan nilai filosofis dalam kemasan pementasannya, (2) Wayang Parwa Sukawati banyak diminati wisatawan manca negara yang memiliki peranan transformatif pada kesenian ini melalui beragam prototipe yang kemudian dikenal hingga ke Mancanegara, (3) Wayang Kulit Parwa Sukawati mampu beradaptasi menghadapi perkembangan era globalisasi.
\end{abstract}

Kata Kunci: Eksistensi, Wayang Kulit Parwa, Globalisasi

This article examines the existence of Sukawati Parwa Leather Puppets in the Era of Globalization. The survival of Sukawati Parwa leather puppets in the Globalization era includes the following factors: (1) Growth of Creativity and Innovation Power of Sukawati Puppet Puppets in the Face of Globalization Era, namely the development of puppeteers' creativity, but the peculiarities of Sukawati Wayang Kulit performances that emphasize philosophical values in its staging package, (2) Wayang Parwa Sukawati is in great demand by foreign tourists who have a transformative role in this art through a variety of prototypes which became known to foreign countries, (3) Sukawati Wayang Kulit able to adapt to the development of the globalization era.

Keywords: Existence, Parwa Leather Puppet, Globalization

I. PENDAHULUAN

Bali sebagai barometer pariwisata dunia berimplikasi pada terjadinya sentuhan dan proses dialektika dari berbagai macam budaya luar baik yang bersifat tradisi maupun modern. Sehubungan dengan hal tersebut pemerintah daerah Bali sebagai steakholder atas pembangunan budaya dan pemertahanan kearifan lokal Bali sejak awal telah mencanangkan jenis pariwisata yang berkembang di daerah Bali yaitu pariwisata budaya yang dijiwai oleh agama Hindu dan kekhasan yang dimiliki disebabkan reputasi pulau Bali sebagai surya pariwisata (Picard 2006 dan Ardika 2007).

Khasanah seni budaya dengan adat istiadat dan kepercayaan setempat yang berbeda, tentu mempunyai karakteristik religiusitas sebagai keunikan dan wujud kreatifitas, baik dalam bentuk maupun sistem kepercayaannya. Realitas ini sebagai salah satu bukti bahwa peradaban masa lalu yang mengagumkan, merupakan salah satu komponen yang membuat pulau Bali memiliki nama harum sampai ke kancah 
internasional. Realitas tersebut, merupakan kebanggaan bagi masyarakat, mengingat di sisi lain hal tersebut dapat memeberikan inspirasi dalam kehidupan estetik dan religius. Hal itu dapat dibuktikan melalui berbagai aktifitas masyarakat salah satunya melalui kegiatan berkesenian sebagai rutinitas yang kerap dilaksanakan masyarakat Bali.

Dari berbagai dimensi kesenian yang mengidentitas pada masyarakat Bali terdapat sebuah kegiatan seni yang dapat dikatakan sebagai ikon atas transformasi sosio religius masyarakat Hindu di Bali. Kesenian tersebut adalah Wayang Kulit, yang telah dikenal masyarakat Bali sebagai salah satu media transformasi ajaran Hindu yang kerap dipentaskan ketika upacara keagamaan baik dalam tatananan spiritualnya sebagai Kesenian Sakral, maupun dalam dimensi Profan yang sarat dengan nilali religious melalui tutur (filsafat religius) dari Sang Dalang yang terintegrasi melalui penggalan epos Hindu seperti Ramayana dan Mahabarata.

Sehubungan dengan pandangan tersebut, tentunya wayang kulit sebagai salah satu media transformasi religius bersifat tradisional memiliki peranan penting dalam interpretasi ajaran Hindu sebagaimana telah diterima masyarakat Bali saat ini. Hal ini didasari atas berbagai temuan yang memuat tentang eksistensi Wayang Kulit sebagai salah satu kegiatan seni tradisional yang sangat diminati masyarakat sejak jaman terdahulu. Berbagai bukti otentis menyatakan bahwa wayang kulit memiliki peranan penting dalam perkembangan peradaban masyarakat bali ditandai dari ditemukannya tulisan berupa prasasti yang memuat tentang wayang sebagai salah satu media pemujaan pada saat tersebut.

Prasasti Bebetin yang berangka tahun 896 Masehi. Adapun isi prasasti tersebut adalah sebagai berikut:

...pande emas, pande besi, pande temaga pemukul (juru tabuh bunyi-bunyian), pegending (biduan), pabunjing (penari), parpadaha (juru gupek), pabangsi (juru rebab), pertapukan (topeng-tapel), perbwayang(wayang)..........turut Dipanglapuan di Singamandawa (dibuat oleh pegawai di Singamandawa) dibulan beka (bulan ke X), hari pasaran Wijayamanggala, tahun saka 818 (896 Masehi) yaitu pada pemerintahan Raja Ugrasena di Bali, (Bandem 1976:3)

Berdasarkan sumber tersebut di atas, dapat dikatakan bahwa pementasan Wayang Kulit telah lama dikenal masyarakat Bali sebagai sebuah media pertunjukan yang bersifat sakral (religius), maupun sebagai sebuah hiburan yang dapat dinikmati masyarakat dalam beberapa kesempatan. Hal ini menandakan bahwa Wayang Kulit memiliki arti penting sebagai sebuah media komunikasi, mengingat melalui pementasannya masyarakat atau penonton memperoleh pesan-pesan religius sebagai landasan berpikir yang tersirat dari babak-babak pementasan sebagaimana disampaikan dengan apik oleh seorang dalang.

Sehubungan dengan keberadaan Wayang Kulit khususnya pementasan wayang kulit Parwa tentunya terdapat demikian banyak masalah krusial yang berkaitan erat dengan masih bertahannya kesenian ini dalam kehidupan masyarakat Bali. Dalam mempertahankan kesenian ini, banyak didapati adanya pembaharuan terhadap bentuk ataupun struktur baik melalui pola pementasan, daya kemas, maupun piranti yang digunakan dalam pementasannya. Dengan kata lain, modernisasi memiliki pengaruh kuat terhadap masyarakat sehingga hal-hal yang bersifat tradisionalpun hendak di revitalisasi melalui unsur-unsur modern. Beberapa bentuk gerakan globalisasi yakni revolusi dan pengaruh prilaku konsumtifitas, hegemoni dan modernitas yang berimplikasi pada paradigma berpikir masyarakat terhadap esensialisme estetika kontemporer.

Terbukti dewasa ini masyarakat seakan hanyut dalam arus deras media modern, dan meninggalkan pola kehidupan tradisi yang adi luhung. Dalam situasi ini telah terjadi pergeseran dan kekaburan budaya. Buktinya tradisi dan budaya lokal ditinggalkan dan 
masyarakat beralih pada prilaku hidup yang mengedepankan modernitas dan teknologi sebagai kebutuhannya. Sehubungan dengan hal tersebut, kesenian wayang kulitpun tidak kuasa mempertahankan diri dari pengaruh kehidupan global yang dominan dibentuk oleh teknologi kontemporer. Dalam keadaan ini seniman dalang akan berusaha mengkemas pertunjukkannya setara dengan kebutuhan masyarakat global. Contohnya, banyak pertunjukkan wayang kulit dikemas dengan rekayasa teknologi dan mengedepankan dialog-dialog humor bahkan berbau porno. Jadi pementasan wayang kulit sekarang cenderung seperti lawak atau humoris. Semua dilakukan dengan tujuan agar penonton bisa tertawa, karena pementasan dikatakan gagal apabila tidak ada penonton yang tertawa.

Era globalisasi telah memaksa tradisi berkesenian klasik berubah, bahkan meninggalkan bentuk aslinya. Tentunya menjadi masalah pelik ketika masyarakat mulai jauh dari salah satu tradisi khususnya Wayang Kulit yang telah lama menjadi media transformasi religius. Hal tersebut dilaksanakan guna mempertahankan popularitas kesenian ini dari semakin melemahnya daya tonton masyarakat untuk menikmati kesenian wayang. Melemahnya keinginan masyarakat umum dalam menikmati pementasan wayang menjadi salah satu indikasi dari modifikasi wujud pementasan wayang kulit yang dulunya sarat akan nilai estetika dan filosofis menjadi sebuah tontonan komersial yang sarat dengan banyolan.

Dibia (1995 51-68) dalam artikelnya yang berjudul "Dari Wacak ke Kocak", menyoroti terjadinya pergeseran pergelaran wayang dari tuntunan menjadi tontonan. Pementasan wayang pada jamanya Dalang Granyam Sukawati tahun 1950 sampai dengan tahun 1960an sungguh sangat mantap mecelek (bermakna) dan wacak (analitis). Sedangkan di jaman sekarang sudah menjadi guyu dan kocak. Pergeseran ini terjadi bersamaan dengan melemahnya mutu kesenian lainya sejalan dengan perkembangan masyarakat modern yang lebih menuntut efisiensi. Hal senada juga menjadi salah satu nilai jual dari kesenian wayang yang populer dengan ikon "Cenk-Blonk" merupakan sebuah trobosan dengan dalih untuk mempertahankan kesenian wayang tanpa menghilangkan nilai estetika dalam pementasan, namun telah memodifikasi sakralitas dan tradisionalitas pementasan wayang kulit menjadi sesuatu yang berbau humoris dengan nuansa modern.

Namun dibalik semakin maraknya perombakan yang terjadi dalam dunia pewayangan Bali baik melalui faham pementasan inovatif dan pembaharuan lain yang saat ini sedang gencar digiatkan seniman wayang, terdapat sebuah pemandangan menarik yang ditunjukkan oleh salah satu paham atau pakem pewayangan Bali yang sampai saat ini masih tetap eksis dengan bertahan pada sisi klasik religius dari pementasan wayang tersebut. Wayang Kulit Parwa Sukawati atau lebih akrab dikenal dengan julukan wayang pakem Sukawati adalah salah satu model pementasan wayang kulit Bali yang telah memiliki citra khusus dimata masyarakat khususnya penikmat pementasan wayang di Bali. Sebagai salah satu dari sekian banyak model atau pakem pewayangan, pakem Sukawati dikatakan sebagai salah satu pementesan yang berhasil menggabungkan bagian integral dalam pementasan wayang seperti gending, tabuh, tetikes, tanjek dan sebagainya menjadi satu kesatuan yang harmonis sehingga banyak digunakan sebagai dasar untuk mencari proporsi pementasan yang menarik.

Sebagaimana umum diketahui bahwa dewasa ini pementasan wayang Kulit Bali telah mengalami evolusi menjadi wayang kulit Bali Modern yang ditandai melalui semakin banyaknya seniman wayang yang mengadopsi teknologi modern dan gaya kemas modern untuk meningkatkan nilai jual dari pementasan ini, tidak berpengaruh pada pakem pewayangan Sukawati yang justru mempertahankan kekhasannya sebagai salah satu pementasan wayang tradisional. Hal ini dapat dilihat melalui demikian banyak 
dalang yang tetap memilih naturalitas dari pementasan wayang Bali sebagai identitasnya.

Terkait dengan hal diatas, almarhum Ketut Madra mengatakan bahwa Wayang Kulit Parwa Sukawati mempunyai ciri yang khas yaitu pementasannya diikat oleh gending gender, (Bandem 1981:6). Pertunjukan wayang kulit sukawati dengan kekhasan nada suara, tandak (bebaturan) dan struktur pementasan masih bertahan sampai saat ini. Selain itu, Wayang Kulit Parwa Sukawati dalam pertunjukkannya masih menggunakan kelengkapan tradisional seperti bentuk gambelan, Damar Blencong, dan beberapa kelengkapan lainnya. Tentunya menjadi venomena yang menarik untuk disimak, ketika pakem Pewayangan Sukawati masih tetap bertahan dengan kualitas klasikal yang menjadi karakteristiknya di tengah semakin maraknya seniman dalang yang mulai berbondongbondong membangun pencitraan baru dengan mengadopsi modernisasi kedalam struktural pementasan Wayang Kulit Bali.

Berdasarkan atas fenomena sebagaimana telah disampaikan melalui latar belakang tersebut menjadi alasan mendasar terkait dilaksanakannya penelitian lebih lanjut terhadap kesenian Wayang Kulit Parwa Sukawati.

\section{PEMBAHASAN}

\subsection{Tumbuhnya Kreativitas dan Inovasi Para Dalang Wayang Kulit Parwa Sukawati dalam Menghadapi Era Global}

Tumbuhnya kreativitas dan inovasi para dalang adalah kegiatan yang dilakukan oleh para dalang Wayang Kulit Parwa Sukawati dalam wujud garapan-garapan kreatif dan inovasi yang menjadi kekhasan bagi setiap dalang sesuai dengan kemampuanya masing-masing. Dengan demikian setiap dalang telah melakukan karya kreatif yang dapat menambah perbendaharaan karya-karya kreatif para dalang Wayang Kulit Parwa Sukawati pada era globalisasi

Dalam menumbuhkan kreatifitas dan inovasi para dalang Sukawati melakukan pembaharuan adegan dengan menambahkan garapan-garapan baru untuk memperkuat sumber aslinya, sehingga karyanya akan tampil lebih indah dan menarik sesuai dengan perkembangan seni pewayangan pada era globalisasi.

Para dalang Sukawati yang aktif melakukan kreativitas dan inovasi dalam dunia pewayangan adalah dalang I Wayan Wija yang berasal dari Banjar Babakan, Desa Sukawati. Dengan kemampuan dan latar belakang pembelajaran yang sangat kuat, begitu juga masa belajar untuk menekuni dunia pewayangan di Sukawati sangat panjang, dengan sabetan, tetikesan dan olah vokal, menyebabkan dalang I Wayan Wija merasa terpancing untuk melakukan garapan karya baru dalam seni pewayangan sehingga Wayang Kulit Parwa Sukawati tetap eksis pada era globalisasi ini.

Adapun kreativitas dan inovasi yang dilakukan oleh dalang I Wayan Wija adalah: a) lelampahan yang sudah dikembangkan dengan memasukkan filosofi, kritik, saran sehingga pertunjukkan lebih komunikatif. b) tatikesan, yaitu suatu gerak tari wayang seperti tarian rebong yang digarap dengan estetis yang menyerupai tari legong, disesuaikan dengan alunan tabuh gender perebongan dihiasi pukulan cepala. c) Kreativitas adegan perang panakawan sangut dengan merdah yang memasukan unsur pertarungan tinju, sehingga memancing ketawa penonton. d) Kreativitas dalam bentuk wayang, I Wayan Wija banyak membuat bentuk wayang baru seperti binatang, raksasa, tokoh panakawan, semua bentuk wayang diciptakan untuk memperkuat dan memperkaya pertunjuka Wayang Kulit Parwa Sukawati. Sehubungan dengan hal tersebut I Wayan Wija mengatakan: 
"Saya berusaha menampilkan karya terbaru saya namun tidak terlepas dari pakem tradisi Wayang Kulit Parwa Sukawati, seperti Wayang Kaca Sinar Maya, karya saya sendiri. Saya mengkemas dengan baik menjadi seni pertunjuka wayang yang menyatu dan serasi” (wawancara dengan dalang I Wayan Wija , 05 Juli 2015)

Terkait dengan garapan prototife wayang sinar maya garapan dalang I Wayan Wija dapat dilihat pada gambar di bawah ini

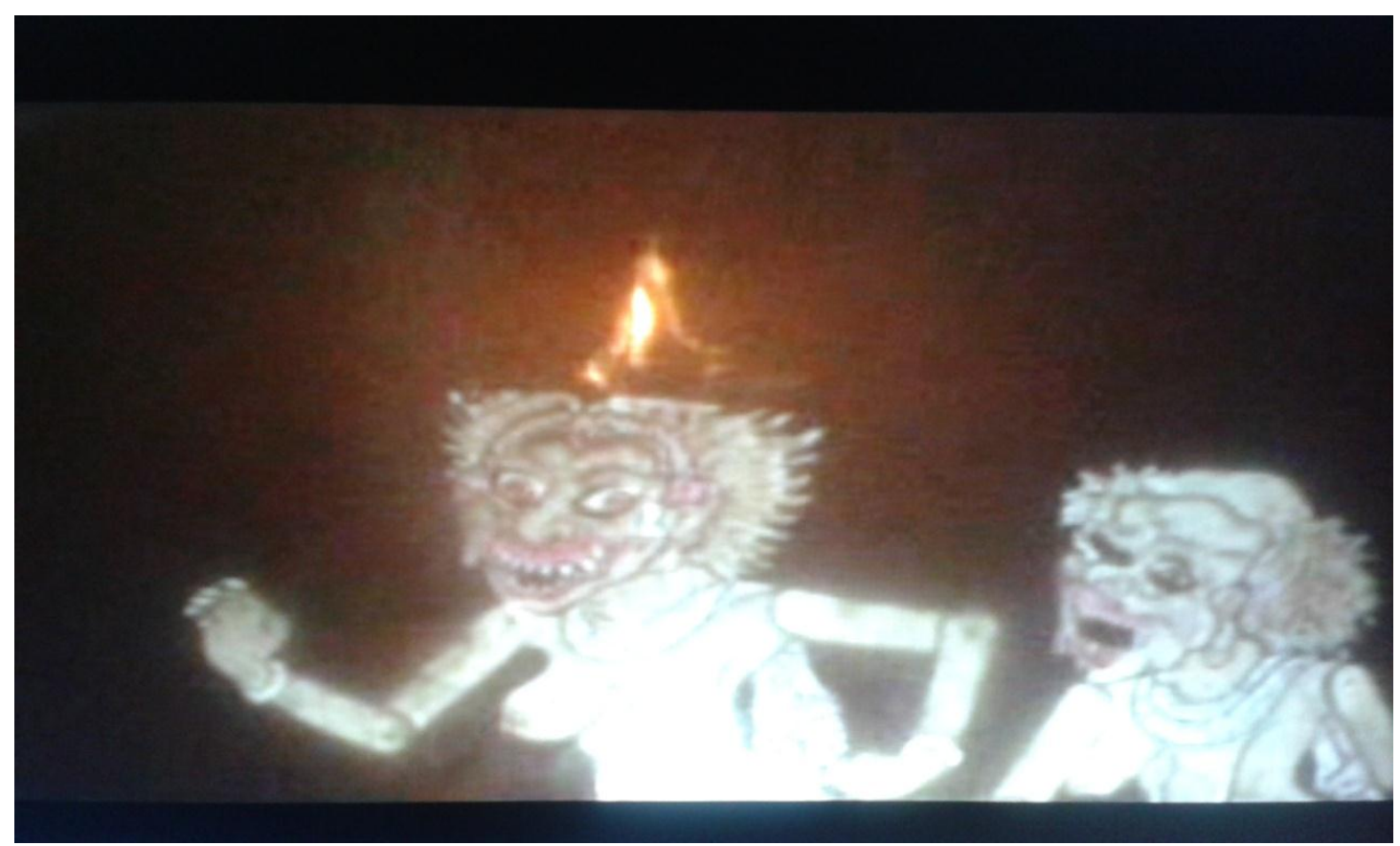

Pementasan Wayang Kaca Sinar Maya oleh I Wayan Wija

(Dok I Nyoman Sudanta, 2015)

Uraian di atas menunjukan kreativitas seni dalang I Wayan Wija dalam pementasannya sebagai usaha mempertahankan eksistensi Wayang Kulit Parwa Sukawati pada era globalisasi agar tidak ketinggalan zaman.

Selanjutnya kreativitas dalang I Made Juanda yang juga kelahiran Banjar Babakan, Desa Sukawati, dengan umur yang masih muda sebagai murid kesayangan dari dalang I Ketut Madra (almarhum), ia cukup mampu untuk berkreativitas dan berinovasi. Dalang muda I Made Juanda beraliran Wayang Kulit Parwa klasik versi Sukawati. Kreativitas yang menonjol yang dilakukan oleh dalang I Made Juanda yaitu tabuh pengiring dengan batel gender. Hal tersebut dilakukan I Made Juanda agar nuansa pewayangan parwa masih tampak jelas dan tidak terkesan seperti pertunjukan Wayang Kulit Ramayana. Selain iringan gambelan, pendalaman filsafat juga menjadi kreativitas dari dalang I Made Juanda. Terkait dengan tersebut, ia juga mengatakan sebagai berikut.

"Saya menggunakan pengiring tabuh batel, agar dalam pementasan Wayang Kulit Parwa Sukawati tidak terkesan sepi, dengan kedengaran lebih ramai sehingga masyarakat tertarik untuk menonton, setidaknya para dalang Wayang Kulit Parwa Sukawati masih mampu beraktivitas pada era globalisasi ini'(wawancara dengan I Made Juanda, 16 Juli 2015).

Usaha yang dilakukan oleh dalang I Made Juanda dengan menggunakan tabuh pengiring batel gender, dengan harapan mampu menarik minat penonton sudah barang 
tentu untuk mempertahankan eksistensi Wayang Kulit Parwa Sukawati. Usaha tersebut di atas membutuhkan pemikiran yang profesional sehingga dalam pertunjukannya mampu membius sirkulasi kekurangtahuan masyarakat dalam ranah kreativitas dengan kemasan yang menarik. Kondisi ini ternyata yang dimaksudkan oleh Dalang Sija sebagai sebuah konsep yang diistilahkan dengan Guru loka. Hal ini dinyatakan dalam wawancaranya, seperti sebagai berikut:

Seorang dalang hendaknya mampu menjadi guru loka dalam masyarakat. Guru loka yang dimaksud adalah mempelajari semua ilmu pengetahuan, tentang Brahmana Tatwa, kepemimpinan, politik, pertanian, perdagangan, nelayan, seluruh aspek kehidupan manusia, binatang, tumbuhan, mampu memberikan tuntunan dalam memaknai kehidupan beragama, memberikan contoh langsung dalam kehidupan sehari-hari, mentaati konsep dan ajaran agama, berperan aktif dalam kehidupan religius, mampu memberikan pandangan-pandangan dalam kehidupan berdasarkan ajaran agama, menyampaikan pesan moral dan spiritual dalam pementasan, dan mampu mempertahankan nilai luhur dari kehidupan budaya masyarakat, (wawancara dengan dalang I Made Sija, 17 Juli 2015).

Pernyataan tersebut bisa digunakan sebagai alasan mengapa Wayang Kulit digunakan sebagai media transformasi nilai religius dan kebudayaan yang kerap digunakan sebagai media transformasi dan komunikasi budaya pada generasi muda. Pementasan Wayang Kulit merupakan media transformasi yang dalam hal ini memberikan pandangan-pandangan sekaligus konsep ajaran Hindu kepada masyarakat. Dengan ini secara tidak langsung masyarakat memperoleh pesan religius melalui reaksi estetika ketika menikmati pertunjukan wayang yang sarat akan nilai-nilai kehidupan. Keuntungan lain dari bentuk pementasan wayang kulit adalah diperolehnya tuntunan ajaran agama dalam kehidupan sehari-hari melalui pementasan dan teladan yang ditampilkan dalam pementasan tersebut. Sekali lagi, dalam hal ini dalang sebagai komunikator memiliki peranan penting dalam mengapresiasi dan menyajikan pementasan yang lugas, menyentuh dan mampu diterima masyarakat sebagai sebuah renungan positif.

Dalam hubungan antara agama dan kesenian akan tampak jelas dalam sistem ritus dan upacara, serta peralatan upacara. Terutama dalam kehidupan beragama Hindu di Bali yang selalu berkaitan dengan ritual yang cukup besar dan penuh nilai seni. Jika diamati secara fisik akan tampak jelas bahwa apapun yang dilakukan oleh masyarakat Hindu Bali dalam melaksanakan ajaran agamanya adalah dengan nilai estetika atau kesenian. Kesenian yang dilaksanakan berkaitan dengan pelaksanaan upacara agama Hindu akan menumbuhkan emosi keagamaan sehingga umat merasakan itu sebagai hal yang penuh nilai kesucian.

Berbagai macam pendapat tentang hubungan agama dan kebudayaan mengindikasikan bahwa keduanya saling terkait erat. Geertz (1992:11) menekankan pada agama sebagai sekumpulan persepsi manusia tentang simbol-simbol sakral. Menurutnya, simbol-simbol sakral itu merubah persepsi manusia ke dalam kecenderungan-kecenderungan akan kewajiban-kewajiban terhadap sesuatu yang dinilai bersifat religius. Misalnya, aktivitas puasa menjadi bagian dari agama ketika digunakan tidak sekedar untuk mengurangi berat badan, tetapi lebih ditujukan untuk sesuatu yang bersifat pisikis atau untuk dunia yang lebih abstrak. Dalam bidang kesenian misalnya, tugu batu (palinggih) yang dibuat indah berukir tidak saja sekedar akan bernilai seni tinggi tetapi lebih banyak menunjukkan tentang kebesaran makna yang terkandung dalam tugu itu sebagai tempat pemujaan kepada Tuhan.

Berkaitan dengan fenomena tersebut, ternyata definisi tentang seni yang berhubungan erat dengan kebudayaan dan agama telah beroprasi secara intens melalui 
penggunaan media dalam transformasinya. Dalam rutinitas religius masyarakat Bali, aktifasi dari bentuk kesenian sebagai salah satu dari otentisitas bentuk kebudayaan dapat disaksikan dalam ritus keagamaan. Demikian banyaknya kesenian sakral yang kerap dilibatkan ketika diselenggarakannya upacara keagamaan merupakan keterhubungan silang singkalut yang sebagai pencitraan masyarakat dalam mengapresiasi religi. Hal ini memiliki kesan dan posisi tersendiri apabila bentuk kesenian tersebut dibicarakan dalam konteks religius. Sehubungan dengan hal tersebut, Sukayasa memberikan definisi terkait dilibatkannya unsur kesenian dalam kehidupan masyarakat Bali. (Sukayasa, 2006 :2) menyatakan bahwa Dalam terminologi Hindu Satyam-Siwam-Sundharam 'kebenarankebajikan-keindahan' adalah tiga dimensi Realitas Suci yang keberadaan-Nya berupa semesta dan segala isinya. Pandangan ini adalah dasar dari sistem pemujaan masyarakatHindu dalam menginterpretasi agama sebagai sebuah paham kehidupan. Dimensi keindahan dalam hal ini berarti adalah segala sesuatu yang memiliki nilai estetik yang dapat diberikan sebagai warna-simbol dalam pendakian spiritual termasuk aktifitas tari sakral seperti pementasan Wayang Kulit dalam rangkaian acara agama.

Seni sakral berfungsi sebagai media yang terkonseptual di dalam rangkaian upacara. Artinya kesenian yang bersifat sakral merupakan sesuatu bentuk estetis sebagai perantara Bhakti yang berperan secara langsung terhadap pelaksanaan upacara. Namun tidak semua bentuk tarian dikategorikan ke dalam konteks tersebut, terkait definisi serta fungsionalismenya masing-masing. Berbicara mengenai eksistensi seni tari, terkait dengan fungsinya masing-masing dapat diklasifikasi yaitu : seni wali adalah bentuk kesenian tari yang harus ada dalam pelaksanaan upacara (yadnya), seni bebali adalah bentuk kesenian yang hanya berfungsi sebagai aed (pengiring) dan seni balih-balihan adalah bentuk tarian yang mengkhusus sebagai hiburan (Bandem, 2002:87). Atas dasar kenyataan tersebut pertunjukkan seni wayang dapat digolongkan menjadi 3 macam yaitu: (1) Wayang Wali yaitu wayang yang mempunyai fungsi sebagai bagian dari keseluruhan upacara keagamaan yang dilaksanakan. Contohnya adalah Wayang Sapuh Leger, Wayang Sudamala. (2) Wayang Bebali yaitu: pertunjukkan wayang yang berfungsi sebagai pengiring upacara di pura atau dalam rangkaian upacara panca yadnya. Contoh yang termasuk rangkaian ini adalah Wayang Lemah. (3) Wayang Balih-balihan yaitu: pertunjukkan wayang untuk tontonan untuk umum yang fungsinya di luar seni wali dan seni bebali yang menitik beratkan pada fungsinya sebagai seni hiburan.

Terkait dengan pandangan tersebut, menunjukan bahwa kesenian sakral merupakan salah satu bagian yang terbangun integral dalam kehidupan masyarakat Bali. Dengan kata lain, Wayang Kulit Parwa sebagai salah satu bentuk pementasan wayang yang berasal dari epos Mahabarata merupakan salah satu bentuk yang bisa dikategorikan dalam pementasan sakral apabila seni pertunjukan wayang tersebut difungsikan dalam rangkaian upacara keagamaan. Hal ini juga mempengaruhi eksistensi dari bentuk kesenian ini tetap hidup dalam budaya religius masyarakat Bali karena adanya keterkaitan pelaksanaan upacara keagamaan terhadap piranti pelengkap dari indikator kesuksesan sebuah upacara berdasarkan konteks tatanan upacara itu sendiri.

Berkaitan dengan perihal tersebut informan I Made Sukadana seorang dalang dan guru pedalangan di SMK N 3 (kokar) Sukawati Gianyar (wawancara tanggal 17 Juli 2015) menyatakan bahwa:

Pementasan Wayang Lemah dalam upacara keagamaan dari sekian banyak bagian yang harus ada dalam pelaksanaan yadnya secara tidak langsung adalah merupakan salah satu peluang supaya tetap eksisnya Wayang Kulit Parwa Sukawati. Dalam setiap kesempatan tersebut, biasanya pementasan Wayang Lemah selalu digelar apabila dalam rangkaian upacara menggunakan pemuput seorang Pandita. Tingkatan penyelenggaraan upacara ini memberikan ruang lebih banyak bagi 
dalang untuk mengevaluasi kemampuannya sekaligus memberikan kesempatan bagi generasi muda dalam upaya meningkatkan kemampuannya dalam menjalani aktifitas sebagai dalang untuk pelestarian kesenian Wayang Kulit Parwa Sukawati.

Jadi berdasarkan atas pandangan tersebut di atas, dapat ditarik sebuah kesimpulan bahwa kegiatan seni berupa pementasan Wayang adalah sebuah realita keagamaan yang senada dengan pergerakan kebudayaan sebagai sebuah perpaduan yang demikian erat dimana agama memberikan ruang khusus bagi kebudayaan daerah dalam mengeksplorasi tradisinya sekaligus memdapatkan upaya penyelamatan lewat sinergi yang terkait kedalam kehidupan ritus agama. Begitu juga dengan eksistensi Wayang Kulit Parwa Sukawati pada era globalisasi.

\subsection{Wayang Parwa Sukawati Banyak Diminati Wisatawan Manca Negara}

Pengaruh yang nampak dari pesatnya pembangunan adalah terjadinya Perubahan sosial budaya dalam masyarakat tradisional, yakni perubahan dari masyarakat tertutup menjadi masyarakat yang lebih terbuka, dari nilai-nilai yang bersifat homogen menuju pluralisme nilai dan norma sosial merupakan salah satu dampak yang dirasakan sebagaimana yang dikemukakan oleh Ahmadi Abu (2004 : 14) yaitu, perubahan sosial dan budaya meliputi berbagai bidang kehidupan dan merupakan masalah bagi semua institusi sosial seperti: industri, agama, keluarga, perekonomian, pemerintahan, perkumpulan-perkumpulan dan pendidikan.

Untuk itu sudah selayaknya wisatawan yang datang dapat dijadikan alternatif penggerak perekonomian sehingga menjadi sumber pendapatan dengan mengajari seni pewayangan. Wisatawan yang berminat belajar memainkan gender, mendalang, dan juga yang berminat membeli wayang sebagai koleksi. Dengan bersandarkan pada tatanan tradisi, kepiawaian para dalang Sukawati untuk mementaskan seni pertunjukan wayang, kekhasan Wayang Sukawati yang mempertontonkan olah vokal dalam tandak/ bebaturan, gerak wayang (tetikesan) yang mengandung unsur estetis, sehingga para wisatawan yang datang ke Sukawati merasa tertarik untuk mempelajari style pertunjukan Wayang Kulit Parwa Sukawati. Para wisatawan tua maupun muda begitu banyak yang belajar olah vokal untuk menjadi dalang gaya Sukawati seperti Miko Katayose, Yu Kako, pelajar yang berasal dari negeri Sakura/Jepang ini, sudah sering bolak-balik Bali, bahkan sudah begitu lama mengenal Wayang Kulit Sukawati. Nabuo Tani (berkewargaan Jepang), belajar memainkan gender wayang pada I Made Juanda dengan sangat tekun sehingga ia bisa menguasai beberapa lagu dari permainan gender tersebut. Setelah bisa memainkan beberapa tabuh gender, Nabuo Tani lebih tertarik lagi untuk mempelajari olah vokal untuk bisa menjadi dalang yang beraliran style Sukawati. Ia sangat tertarik untuk mempelajari Wayang Kulit Parwa Sukawati karena masih kental dengan nuansa tradisi, seperti yang disampaikan saat wawancara dirumah dalang I Made Juanda dengan bahasa Indonesia tetapi masih kental dengan logat jepangnya sebagai berukut.

"Saya tertarik mempelajari Wayang Sukawati, karena pakem pementasanya sesuai dengan struktur pementasan tradisi, begitu juga, lampu yang digunakan masih tradisi menyebabkan bayangan wayang kelihatan bergerak, dan yang paling saya suka kekhasan dari Wayang Kulit Sukawati adalah dengan menggunakan 4 gender, sehingga kedengaranya tidak terlalu bising, seimbang antara vokal dalang dengan pengiring gambelan, manis dan serasi, yang menimbulkan rasa nikmat untuk ditonton dan didengarkan, wawancara dengan Nabuo Tani,16 Juli 2015)”.

Mahasiswa dari Inggris yang ingin mengenal Wayang Sukawati lebih dekat dengan mempelajari wayang style Sukawati di rumah dalang I Wayan Narta. Ia belajar dari 
pengenalan bentuk dan nama wayang, karakter, suara dari masing-masing bentuk wayang, dan melihat langsung bagaimana proses pembuatan bentuk Wayang Sukawati. Untuk lebih jelasnya kegiatan mahasiswa Inggris yang belajar seni wayang dengan dalang I Wayan Narta, bisa dilihat pada gambar dibawah ini.

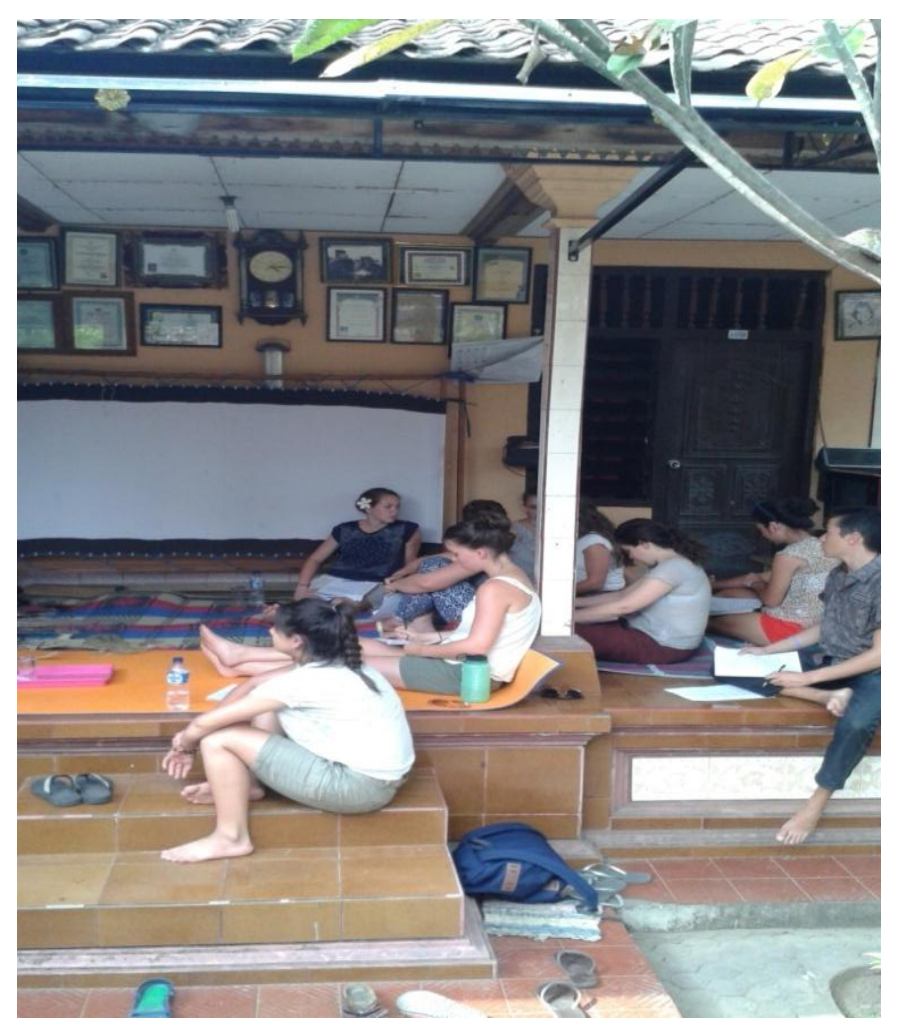

Mahasiswa Asing sedang belajar seni wayang pada dalang I Wayan Narta.

(Dok I Nyoman Sudanta,2015)

Sesuai dengan pengamatan peneliti, setiap pementasa wayang saat upacara keagamaan maupun pementasan wayang balih-balihan di malam hari, seringkali melihat wisatawan asing yang menonton. Walaupun mereka tidak paham sepenuhnya tentang dialog ucapan dari dalangnya, namun mereka menonton dengan hikmat dan sesekali mengabadikan dengan kameranya. Dengan pengetahuan seni dan sistem religi yang mereka dapatkan, dari pertunjukan organisasi sekha wayang yang pentas mampu memberi gambaran tentang kehidupan sosial masyarakat Bali.

Organisasi Sosial, Pengetahuan, Kesenian, dan sistem Religi. Bali sebagai salah satu daya tarik bagi wisatawan dari seluruh dunia, dan berkat keunikan- keunikan serta keindahan-keindahan yang dimilikinya terutama pada bidang sosial budaya yang bersumber pada ajaran Agama Hindu. Dengan adanya keunikan-keunikan serta keindahan-keindahan tersebut mengundang para wisatawan untuk turut menikmatinya secara langsung.

Menyadari potensi pulau Bali yang tidak mungkin lagi dikembangkan dalam bidang pertanian dan pertambangan maka satu-satunya potensi dan pengembangan pulau Bali adalah industri pariwisata. Oleh karena itu penanganan terhadap industri pariwisata tersebut hendaknya terpadu jangan sampai merugikan agama dan kebudayaan rakyat Bali. 
Kehadiran dari para wisatawan tersebut, baik langsung maupun tidak langsung menimbulkan pengaruh-pengaruh yang positif maupun negatif dalam berbagai aspek kehidupan masyarakat Bali.

Sehubungan dengan beberapa pandangan tersebut, dinamisme kesenian sebagai salah satu produk dari kebudayan Bali juga memiliki peranan penting atas perkembangan pariwisata Bali. Dengan kata lain, kesenian tradisional seperti Wayang Kulit di Desa Sukawati juga memiliki substansi yang signifikan sebagai salah satu kegiatan yang berpengaruh pada pariwisata. Perkembangan tersebut dapat dilihat melalui semakin meningkatnya permintaan pasar tentang souvenir Wayang Kulit ini. Dengan demikian, kesenian wayang sebagai salah satu kegiatan melalui barang kerajinan juga memiliki peranan penting tentang dimensi budaya Wayang Kulit Bali di dunia internasional.

Terkait dengan hal diatas, pariwisata dan komunikasi yang terjadi dalam dimensi kegiatan ini telah menghantarkan sisi tradisi estetik dari Wayang kulit sehingga banyak kemudian seniman-seniman asing yang sengaja datang untuk mempelajari baik secara teknik, sejarah dan perkembangan wayang tradisional sebagai sebuah khasanah seni yang Adiluhung.

\subsection{Wayang Kulit Parwa Sukawati Mampu Beradaptasi Menghadapi Perkembangan Pada Era Globalisasi \\ Untuk mempertahankan diri dari pengaruh globalisasi, para dalang bersama} masyarakat pendukung seni pertunjukan Wayang Kulit Parwa Sukawati mengadakan langkah-langkah aktivitas yang bisa membuat eksisnya Wayang Kulit Parwa Sukawati pada era globalisasi sekarang ini. Semua properti seni pewayangan, dramanisasi, vokal, sabetan gerak wayang, permainan cepala yang kropaknya menggunakan opak-opakan (tabing kananya Kropak dipasang agak longgar, ngontel), sehingga memudahkan para dalang membuat ritma-ritma untuk menghidupkan tetangkisan wayang. Di sisi lain para dalang kembali berkiblat ke pakem tradisi yang diwarisi dari dahulu, dan mengkemas suatu cerita yang menarik, diperkuat dengan filsafat, tatwa-tatwa, tutur-tutur yang ada hubunganya dengan kehidupan masa kini, dengan lelucon yang bersifat menghibur tetapi juga memberi tuntunan moralitas yang adiluhung dan adiluhur. Usaha para tokoh seni pedalangan yang juga didukung oleh pemerintah Kabupaten Gianyar dengan membentuk Pepadi yaitu Persatuan Pedalangan Indonesia Gianyar. Sebagai Suatu wadah pembinaan seni pedalangan di Kabupaten Gianyar. Wadah tempat berkumpulnya para dalang untuk membicarakan dan mengusahakan tentang pelestarian dan berkelanjutanya seni pedalangan pada masa yang akan datang.

Seiring derasnya arus globalisasi, dan mampu beradaptasi dengan perkembangan zaman, dalang I Wayan Wija mengali mutiara-mutiara yang ada pada seni Wayang Kulit Parwa Sukawati. Dengan menciptakan bentuk wayang yang baru, gerakan wayang, vokal yang estetis, dan instrumen pengiring adalah gambelan saih pitu. Prakarsa inovasi I Wayan Wija sebagai inspirasi pada dalang muda lainya di Sukawati. Dengan karya-karya inovasi sebagai bentuk adaptasi terhadap era globalisasi, maka dalang muda I Ketut Sudiana (putra I Wayan Narta) berkarya dengan garapan bernama Wayang Plastik. Wayang plastik I Ketut Sudiana yang berupa karya inovasi berhubungan dengan garapan ujian meraih gelar Magister Ilmu Seni pada Institut Seni Indonesia (ISI) Solo. Adaptasi era global juga diikuti I Wayan Mardika (putra almarhum I Ketut Madra) dengan garapanya memakai layar lebar, lampu penerang listrik dan LCD, sehingga mampu beradaptasi dengan perkembangan zaman. Semua proses adaptasi para dalang yang diuraikan di atas, tidak terlepas dari kekhasan Wayang Sukawati dengan lakon yang bersumber dari cerita Mahabharata.

Uraian tersebut diatas membuktikan bahwa Wayang Kulit Parwa Sukawati 
mampu beradaptasi menghadapi perkembangan era globalisasi.

Dengan kegiatan rutinitas yang diselenggarakan para dalang di Desa Sukawati untuk mencetak generasi dalang baik dari kaum tua, kaum remaja, bahkan dari usia dini, seperti seumur cucu dari bapak I Wayan Narta sudah menggeluti dunia wayang dari kelas 1 Sekolah Dasar berkencimpung di dunia wayang, dengan rajin dan tekun belajar memainkan wayang yang merupakan suguhan sehari-hari dalam masa kecil di desanya sehingga dengan usia yang masih terlalu kecil mengukuti lomba dalang cilik yang pertama kali diselenggarakan media lokal Bali TV Denpasar.

Karir remaja yang tidak mau ketinggalan mengenyam pendidikan seni pedalangan sebagai generasi penerus pedalangan Sukawati, seorang anak remaja yang bernama I Putu Bratanatya yang mementaskan seni Wayang Kulit gaya Sukawati dalam acara lomba dalang remaja pada ajang Pesta Kesenian Bali tahun 2014 di Art Center yang mendapatkan juara I tingkat remaja. Kemudian jejak itu diikuti oleh dalang remaja dengan gaya Sukawati yang mewakili Kabupaten Gianyar pada acara Pestival Wayang Ramayana tingkat remaja pada Pesta Kesenian Bali tahun 2015. Dengan perjuangan yang berat dan gigih seorang dalang remaja yang bernama I Putu Sutrena Putra yang baru menginjak umur 17 tahun berhasil merebut juara 1 dalang tingkat remaja yang di bawah asuhan I Made Juanda dan I Wayan Wija, dalang kelahiran Sukawati yang propesional dan populer di dunia pewayangan.

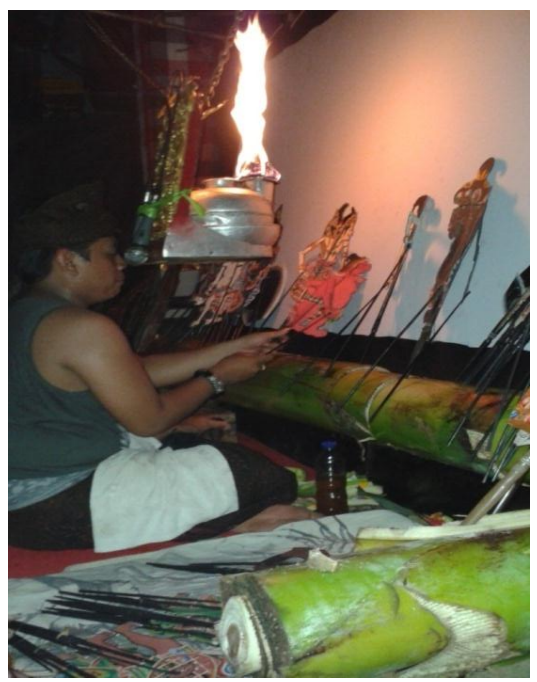

Pentas Dalang Remaja mempertahankan style Wayang Sukawati (Dok. I Nyoman Sudanta 2015) dengan diadakanya lomba megender yang diselenggarakan para sangar, pemerintah Kabupaten Gianyar, begitu juga oleh komonitas seni, untuk menarik minat anak-anak dan remaja belajar memainkan gambelan gender, merupakan usaha melestarikan seni gambelan gender sebagai pendukung utama eksisnya pementasan Wayang Kulit Parwa Sukawati. Hal hasil banyak terbentuk bibit penerus pemain gambelan gender dari usia anak-anak, remaja, sampai usia dewasa. Yang lebih mengagumkan banyak dari anak perempuan yang tertarik dan ikut ambil bagian belajar memainkan gambelan gender, 
kepiawaianya hampir sama dengan kepiawaian anak laki-laki. Pada kesempatan yang baik saat ulang tahun Kota Gianyar tahun 2015 ditampilkan pementasan gambelan gender wayang masal di alun-alun Kota Gianyar yang dikoordinir oleh bapak I Ketut Buda dari Sukawati

Sesuai uraian tersebut di atas, eksistensi pementasan Wayang Kulit Parwa Sukawati akan semakin kuat dan kokoh dengan menyiapkan generasi muda penerus dari dalang cilik, dalang remaja begitu juga pemain gambelan gender pendukung utama pementasan wayang sebagai akar kehidupan dan perkembangan pada era globalisasi. I Made Sija (wawancara tanggal 26 Juli 2015) menegaskan bahwa:

"Bapa ningalin wayang parwa sukawatine waluya cara ipunyan bingin ane suba mentik uli pidan di pempatane, akahne ngeliunan bangsing samah apa buin akah ane muda liu mentik nyilurin akah ane tuwa tur berek, bapa yakin punyan bingine tetep kukuh mejujuk. Yening ada angin baret paling empak carangne apan sube tua umurne, nanging buin mentik embong carangnyane. Yan ipidan liu anake ngetis dibongkol bingine, dagang daluman, dagang bubuh, dagang baju, sangkalanga anake bedak seduk, kebus makejang ngungsi bongkol bingine. Nanging jaman jani langah anake ada di bungkil bingine, yan jaman jani anake ngetis bedak seduk pasti ke swalayan mekejang ade apa buin misi ase (AC), disubane emed pasti buin ngalih ane alami ke bungkil bingine. Patuh care turise emed ya ane modern, ke Bali ngalih ane kuno".

Artinya:

Ibaratkan pohon beringin yang tumbuh begitu lama di perempatan jalan, dengan akar yang banyak sebagai penopang kekuatan pohon tersebut, terlebih lagi banyak akal yang muda tumbuh baru menggantikan akar yang tua dan rapuh niscaya pohon itu akan tetap berdiri kokoh seandainyapun ada yang patah paling hanya cabang atau ranting karena termakan usia tetapi akan tumbuh cabang atau ranting baru. Kalau jaman dulu banyak orang yang berteduh di bawah pohon beringin, ada pedagang daluman (penghilang rasa haus tradisi Bali), pedagang bubur, pedagang baju, sehingga orang yang haus, lapar dan kepanasan, semua menuju ke pohon beringin. Tetapi jaman sekarang jarang orang yang berteduh di pohon beringin, jaman sekarang orang berteduh, haus, lapar pasti menuju swalayan (pasar modern) semuanya adadi sana, apa lagi ada pendingin ruangan (AC). Setelah jenuh dengan dunia global pasti kembali mencari yang alami ke bawah pohon beringin. Sama halnya dengan Turis (wisatawan asing), jenuh ia dengan dunia modern datang ke bali mencari suasana tradisi.

Berdasarkan uraian dalang I Made Sija, kekuatan akar tradisi dari style Wayang Kulit Parwa Sukawati walaupun gerusan jaman globalisasi, akan tetap mampu bertahan keberadaanya (eksistensinya). Pertunjukan gaya wayang inovatif yang sedang berkembang jaman sekarang semuanya juga bersumber pada wayang tradisi gaya Sukawati, dan I Made Sija yakin setelah jenuh dan mentok berinovasi pasti akan kembali ke gaya tradisi Wayang Sukawati. Semangat generasi penerus mempelajari seni pewayangan gaya Sukawati baik yang ada di Desa Sukawati maupun di luar Desa Sukawati, bahkan luar negeri, tumbuh dan berkembang semakin menjamur. Banyak dalang yang belajar dengan gaya Wayang Sukawati untuk mencari ciri khas dan keklasikan Wayang Kulit Parwa Sukawati.

Menurut Nobue Tani (wawancara tanggal 16 Juli 2015) seorang wanita asal Jepang yang belajar memainkan gender dan juga belajar mendalang. Selama di Bali sudah sering ia nonton pementasan wayang Kulit dengan khas dalang yang berbeda, namun ia lebih tertarik untuk menonton dan mempelajari seni pertunjukan wayang tradisi. Dengan lampu 
penerang yang masih tradisi, pakem pewayangan yang masih tradisi sesuai dengan ciri khas gaya Wayang Kulit Sukawati, sehingga ia memilih untuk berguru kepada I Made Juanda. Nobue Tani merasakan alunan suara dalang dengan lagu alasarum yang diiringi gending gender ada suatu keindahan yang menyatu antara vokal dengan instrumen.

Dipertegas oleh Jhon Key, orang Amerika yang menekuni seni Bali, Wayang Kulit Bali yang menggaung namanya di negaranya adalah seni wayang yang masih tradisi. Jhon Key juga menanyakan mengapa kok di Bali orang-orang seneng dalam pementasan wayang memakai lampu listrik, padahal dengan lampu tradisi wayang yang dimainkan itu kelihatan bergerak karena gerakan api dari lampu tradisi tersebut, sehingga wayang kelihatan lebih hidup. Kalau dengan lampu tradisi permasalahnya kelihatan agak gelap, semestinya dibuatkan lampu yang bola apinya lebih besar yang membuat bayangan wayang itu bisa lebih jelas. Di samping itu setiap pementasan wayang menggunakan pengeras suara menggelegar sangat keras seakan memecah telinga. Pementasan wayang jaman dahulu dipergunakan patokan suara gambelan gender, yang perlu pengeras suara hanya Si Dalang untuk menyeimbangan suaranya dengan intrumen gambelan gender, sehingga kedengaranya lebih bisa dinikmati dengan baik, nyaman dan nikmat.

Berdasarkan atas hasil penelitian sebagaimana telah disampaikan dalam bagian ini terdapat hal penting bahwa, Seni Pementasan Wayang Kulit sejatinya merupakan salah satu warisan nusantara yang cukup tua. Sebagai bagian dari perkembangan Kebudayaan Indonesia khususnya di Bali, Wayang memiliki peran sangat penting sebagai media transformasi nilai etika religius, ataupun hiburan yang demikian ditunggu oleh masyarakat. Maka dari itu, pertahanan atas tradisi pewayangan memang menjadi salah satu perihal penting untuk merawat tradisi ini sebagai sebuah kegiatan seni. Sehubungan dengan hal tersebut, Eksistensi Pewayangan khususnya Wayang Kulit Parwa Sukawati telah mampu hadir sebagai pelita kesenian tradisional di tengah gempuran modernisasi yang menggempur kesenian tradisional menjadi sebuah media yang terkomodifikasi. Dengan kata lain, Wayang Kulit Sukawati mampu berdiri dengan mempertahankan keaslian tradisinya sehinngga memiliki nilai penting yang demikian dicari bahkan oleh seniman-seniman asing.

Berdasarkan atas hasil penelitian tentang Eksistensi Pementasan Wayang Kulit Parwa Sukawati maka dapat disimpulkan bahwa kegiatan ini memiliki hubungan dengan teori fungsionalisme Struktural yang menggunakan konstruk pemikiran Parsons yakni ada empat fungsi penting diperlukan semua sistem atau skema AGIL dengan hasil sebagai berikut: 1) adaptation (adaptasi): yaitu kemampuan kesenian ini dalam beradaptasi terhadap jaman. 2) Goal attainment (pencapaian tujuan) yaitu masih eksisnya pementasan wayang sukawati, 3) Integration (integrasi) yaitu terjadinya kesinambungan antara generasi ke generasi, dan 4) Latency (latensi atau pemeliharaan pola) yaitu masih bertahannya pakem pewayangan Sukawati sampai dengan saat ini.

\section{PENUTUP}

Eksistensi Pementasan Wayang Kulit Parwa Sukawati Pada Era Globalisasi meliputi faktor eksternal yakni : a)Tumbuh Daya Kreativitas dan Inovasi Para Dalang Wayang Kulit Parwa Sukawati Dalam Menghadapi Era Globalisasi, yaitu berkembangnya kreativitas para dalang, namun kekhasan pementasan Wayang Kulit Sukawati yang lebih menonjolkan nilai filosofis dalam kemasan pementasannya, b) Wayang Parwa Sukawati 
banyak diminati wisatawan manca negara yang memiliki peranan transformatif pada kesenian ini melalui beragam prototipe yang kemudian dikenal hingga ke Mancanegara, c) Wayang Kulit Parwa Sukawati mampu beradaptasi menghadapi perkembangan era globalisasi.

\section{DAFTAR PUSTAKA}

Agastia, IBG. 1994. Kesusatraan Hindu Indonesia.Denpasar: Yayasan Dharma Sastra

Ardika, I Wayan.2007. Pusaka Budayadan Pariwisata.Denpasar: Pustaka Larasan

Bandem, I Made.1996. Etnologi Tari Bali.Diterbitkan dalam kerja sama dengan Forum Apresiasi Kebudayaan Denpasar-Bali. Yogyakarta: Kanisius.

1978, Pakem Wayang Parwa Bali, Yayasan Pewayangan Daerah Bali

Bandem I Made 1981/1982, Wimba Wayang Kulit Ramayana (Ketut Madra) Proyek Penggalian/Pembinaan Seni Budaya Klasik Tradisional dan Baru

Bugin, Burhan. 2009. Penelitian Kualitatif Komunikasi, Ekonomi, Kebijakan Publik, dan Ilmu Sosial Lainya. Jakarta: Kencana.

Dharmayuda, Suasthawa I Made, 2001: Desa Adat, Kesatuan Masyarakat hokum Adat di Provinsi Bali. Denpasar: Upada Sastra

Dibia, I Wayan. 1995. "Dari Wacak ke Kocak”. Dalam Mudra, Jurnal Seni Budaya, Nomor 3, Tahun III. Denpasar: ISI Denpasar.

Djelantik, A. A. Made, 1999, Estetika Sebuah Pengantar. Bandung: Masyarakat Seni Pertunjukan Indonesia.

2006. Profil Desa Sukawati , Tim Kabupaten Gianyar, Kecamatan Sukawati.

Gulo2002..Metoderiset. Gramedia: Surabaya.

H Malik, 1994, Pemanfaatan Media Dalam Menunjang Kemahiran Menulis Bahasa Arab. Universitas Negeri Malang

Koentjaraningrat. 1982. Sejarah Teori Antropologi. Jakarta : UI- Press

. 2002. Kebudayaan Mentalitas Dan Pembangunan. Jakarta: Pt Gramedia Pustaka Utama

Mantra, I B. 1996.Landasan Kebudayaan Bali. Denpasar : Yayasan Dharma Sastra.

Moleong, J. Lexy. 1991. Metodologi Penelitian Kualitatif. Bandung : PT. Remaja Rosda Karya. 
Mudita, Pande Nyoman Gede. (2012). Transformasi nilai Pendidikan Agama Hindu melalui Pementasan Wayang Lemah, di Desa Bona, Gianyar. Denpasar: Penelitian Tesis ini digunakan sebagai persyaratan dalam menempuh gelar Magister (S2) di Universitas Hindu Indonesia.

Mulyana, Deddy. 2008. Komunikasi Suatu Pengantar. Bandung: PT Remaja Rosda Karya

Mulyono, Sri. 1982. Wayang Asal-Usul, Filsafat dan Masa Depanya. Jakarta: Gunung Agung.

Nawawi, Hadari. H. 1995. Metode Penelitian Bidang Sosial. Yogyakarta : Gajah Mada University Press.

Nurudin. 2007. Pengantar Komunikasi Massa. Jakarta : PT Raja Grafindo Persada.

Pablo Gonzales Casanova, 2001, Fenomena Pedesaan, Intan Pariwara

Palguna, IBM Dharma. 2007. Budaya Kepintaran Sampai Budaya Kekerasan Pikiran. NTB : Sadampatyaksara 